\title{
Strength Performance of Concrete Produced with Volcanic Ash as Partial Replacement of Cement
}

\author{
Agboola Shamsudeen Abdulazeez ${ }^{1}$, Mamman Adamu Idi ${ }^{2}$, Tapgun Justin ${ }^{3}$, Bappah Hamza \\ ${ }^{1,}$ M.Tech Student, Abubakar Tafawa Balewa University Bauchi, Nigeria \\ 2 Abubakar Tafawa Balewa University Bauchi, Nigeria \\ ${ }^{3}$ College of Arts, Science and Technology Kurgwi Shendam, Plateau, Nigeria \\ ${ }^{4}$ Nigeria Army University Biu, Borno, Nigeria
}

\begin{abstract}
There is global need for the preservation of natural resources, reduction of carbon dioxide emission and sustainability of concrete structures; this and other problems associated with material production have fuelled the search for alternative cementing material to produce environment-friendly construction materials. The mining of cement raw materials leads to depletion of natural resources and degradation of environment. Cement production also pollutes the environment due to the emission of $\mathrm{CO}_{2}$. Volcanic ash is suitable material for replacement of cement in concrete production. Chemical composition of volcanic ash as well as the specific gravity, bulk density, workability, compressive strength split tensile strength and flexural strength properties of varying percentage of volcanic ash blended cement concrete and $100 \%$ cement concrete of mix ratio $1: 2: 4$ and water-cement ratio of 0.5 were examined and compared. Slump test and compacted factor test was carried out to check the effect of volcanic ash on the workability of fresh concrete. Volcanic ash partially replace cement in the order of $0 \%, 5 \%, 7.5 \%, 10 \%, 12.5 \%, 15 \%$ and $20 \%$ were cast. The concrete were tested at the ages of 7, 14, 21 and 28 days. The results showed that volcanic ash is a good pozzolan with combined $\mathrm{SiO}_{2}, \mathrm{Al}_{2} \mathrm{O}_{3}$ and $\mathrm{Fe}_{2} \mathrm{O}_{3}$ of $74.8 \%$. The highest compressive strength at 28 days was $29.2 \mathrm{~N} / \mathrm{mm}^{2}$ and $28.3 \mathrm{~N} / \mathrm{mm}^{2}$ at for $10 \%$ and $7.5 \%$ respectively, as compared to plain concrete which was $27.8 \mathrm{~N} / \mathrm{mm}^{2}$; in addition $5 \%$ replacements of cement with volcanic ash present same value with the control concrete. The highest split tensile strength at 28 days was $3.48 \mathrm{~N} / \mathrm{mm}^{2}$ and $3.45 \mathrm{~N} / \mathrm{mm}^{2}$ at for $10 \%$ and $7.5 \%$ respectively, as compared to plain concrete which was $3.42 \mathrm{~N} / \mathrm{mm}^{2}$; in addition $15 \%$ replacements of cement with volcanic ash present same value with the control concrete. The highest flexural strength at 28 days was $4.91 \mathrm{~N} / \mathrm{mm}^{2}$ and $4.83 \mathrm{~N} / \mathrm{mm}^{2}$ at for $10 \%$ and $15 \%$ respectively, as compared to plain concrete which was $4.70 \mathrm{~N} / \mathrm{mm}^{2}$; in addition $5 \%$ and $7.5 \%$ replacements of cement with volcanic ash both present higher value of $4.75 \mathrm{~N} / \mathrm{mm}^{2}$ which is higher than the control concrete. The strength test results indicated that volcanic ash concrete gave better strength compared to control samples. A $\mathbf{1 0 \%}$ replacement of cement with volcanic ash was found convincing and indicate the optimum replacement level of cement. However can be used up-to $15 \%$ replacement level due to its promising result. The research recommends use of volcanic ash as partial replacement of cement in aggressive environment, increased water cement ratio.
\end{abstract}

Keywords - Chemical Properties, Specific Gravity, Bulk Density, Workability, Compressive Strength, Split Tensile Strength, Flexural Strength, Volcanic Ash.

\section{INTRODUCTION}

Cement as a material is used as a major constituent in the production of concrete. Cement as an important constituent of concrete which is gradually becoming expensive compared to other ingredients of concrete and its exploitation is posing threat to the environment. The mining of its raw materials leads to depletion of natural resources and degradation of environment. Its production pollutes the environment due to $\mathrm{CO}_{2}$ emission. The emission of $\mathrm{CO}_{2}$ is such that for every ton of cement produced almost a ton of $\mathrm{CO}_{2}$ is emitted [1 and 2]. In view of this and other problems associated with production and use of cement, a lot of research efforts were made to find an alternative material that will partially or fully replace cement in concrete production.

A way out is replacing a proportion of cement with cheap and available pozzolanic materials. [3] defined pozzolana as "siliceous or siliceous and aluminous material which in themselves have little or no cementitous properties but in finely divided form and in the presence of moisture they can react with calcium hydroxide which is liberated during the hydration of portland cement at ordinary temperatures to form compounds possessing cementitous properties". [4] classify pozzolans as either natural or artificial pozzolan. Natural pozzolans include; clay and shales, opalinc cherts, diatomaceous earth, volcanic ash, volcanic tuffs and pumicites, while Artificial pozzolans include; fly ash, blast furnance slag, silica fume, rice husk ash, metakaoline and surkhi. In view of this, the concept of using volcanic rock in the production of replacement for cement which require little energy in its processing and is environmentally friendly was developed to be used as an alternative to cement in concrete production. Volcanic ash, being one of the classifications of natural pozzolans, is environmentally friendly, economical and accessible. Volcanic ash, referred to as "original pozzolan" or 'natural pozzolan', is a finely fragmented magma or pulverized volcanic rock, measuring less than $2 \mathrm{~mm}$ in diameter, which is emptied from the vent of a volcano in either a molten or solid state [5]. [5] Further state that it has been known for millennia that the mixture of volcanic ash or pulverized tuff (siliceous), with lime produces hydraulic cement. An examination of ancient Greek and Roman structures provide sample evidence of the effectiveness and durability of this cement [5]. Pozzolana have the characteristics of combining with the free lime liberated during the hydration process of Ordinary Portland Cement (OPC) to produce stable, insoluble calcium silicates thus reducing the process of mortar and concrete attacks from sulphates, salts and chloride. Pozzolanic reactions are silica reactions that take place in the presence of calcium hydroxide and water to produce calcium silicate hydrates $(\mathrm{C}-\mathrm{S}-\mathrm{H})$. This $\mathrm{C}-\mathrm{S}-\mathrm{H}$ creates a denser microstructure that increases strength, reduces the permeability of concrete and improves its 
resistance to chemical attack [6]. According to [7] the use of pozzolan to replace OPC in concrete lower heat development during hardening and improve durability of the final concrete structures. Other researches carried out include using Byproducts mineral admixtures such as fly ash, rice husk ash and ground granulated blast furnace slag contribute to improvement of concrete performance (for example, high strength, high durability and reduction of heat of hydration) as well as reduction of energy and carbon dioxide generated in the production of cement. [8] uses fly-ash to replace ordinary Portland cement with fly ash at 20\%, 30\%, 40\%, $50 \%, 60 \%$ and $70 \%$ replacements of cement. The results showed that the compressive strength decreases at 3, 7 and 28 days as the replacement of fly ash approach $30 \%$ replacement. Groundnut shell ash was used by Mahmoud et al., (2012) at $10 \%, 20 \%, 30 \%, 40 \%$ and $50 \%$ as a partial replacements of cement in sandcrete blocks production. The optimum replacement achieved at $20 \%$ with a corresponding strength of $3.58 \mathrm{~N} / \mathrm{mm}^{2}$. However various researchers carried out research on volcanic rock thus [10] is one out of many researchers that carried out a research on Jos Plateau volcanic ash to replaced OPC with 5\%, 10\%, 15\%, 20\%, 30\% and $40 \%$ the results showed that $5 \%$ and $10 \%$ were the best replacement by achieving highest compressive strength. [5] Used volcanic ash from Kerang of Mangu Local Government Area of Plateau State to replaced OPC with 10\%, 20\% and $30 \%$ the results showed that $20 \%$ was the optimum replacement level with greatest compressive strength. Extensive study is needed to find the optimum percentage replacement of volcanic ash which can be used without any effect on the properties of the produced concrete. Also, there is a need to study the possibility of using the volcanic ash as a raw material in the production of cement. Currently world production rate of cement increasing and is expected to grow significantly in the nearest future. This increasing demand for cement is expected to be met by partial cement replacement. This research examined the strength performance of concrete produced with volcanic ash as partial replacement of cement to determine the potential of volcanic ash in produce sustainable concrete.

\section{MATERIALS AND METHODS}

All the materials used for laboratory experiment were procured from the immediate environment. The relevant standards were used in the process of conducting the experiments.

Materials: The materials for this study included, coarse aggregate fine aggregate, Cement, volcanic ash and water. Volcanic ash was sourced from Kerang Mangu local government of Plateau State, Nigeria. It is a rock material which is predominant in the locality. The rock form and its particulate are as a result of volcanic eruption which has been there for decades. The coarse aggregate was obtained from a quarry site within Bauchi metropolis. The fine aggregate was obtained from Bayara River-flow in Bauchi state. The ordinary Portland cement is the brand of Dangote of Grade 42.5 which was procured from vendors within Bauchi metropolis. Samples of bottle fragments collected were washed and dried then crushed. To pulverize the volcanic stone into powder, a locally fabricated mill was used. The ash was sieved through a $75 \mu \mathrm{m}$ sieve.

Chemical Analysis of VA: The volcanic ash was analyzed to determine its suitability as a pozzolana. The chemical analysis was conducted at Sodexmines Nigeria limited Plateau State, Nigeria, using EDXRF method. The machine used to carry out this test was Minipal 4 Energy Dispersive $\mathrm{X}$-Ray Fluorescence. The major oxides, minor oxides and Lost on Ignition (LoI) were measured and recorded.

Workability Tests of the wet VA-Cement Concrete: The Compacting factor test was conducted in accordance with [11]. Slump test was also conducted using the relevant cone for measurements. The tests were conducted in accordance with [11].

Density Test: This was carried out prior to crushing of the concrete specimen. At the end of each curing period, the concrete specimens were weighed using an electric weighing machine balance. Density is calculated as mass of concrete specimen in $(\mathrm{kg})$ divided by volume of concrete cube $\left(\mathrm{m}^{3}\right)$ and expressed in $\mathrm{kg} / \mathrm{m}^{3}$.

Compressive Strength Test for volcanic ash blended cement concrete: The compressive strength test was conducted in accordance with [12]. The 1: 2: 4 mix ratios were adopted using a water cement ratio of 0.5 . The ratio was that of OPC (with replacement levels of VA), fine aggregate and coarse aggregate respectively. The cubes were cast for cement replacement levels at $0 \%, 5 \%, 7.5 \%, 10 \%, 12.5 \%$, $15 \%$ and $20 \%$, and cured for 7 days, 14 days, 21 days and 28 days respectively. For each mix, 3 cubes were crushed to obtain the average strength of the concrete samples. The compressive strength is the ratio of the weight of cube and the cross sectional area.

Split Tensile Strength Test for volcanic ash blended cement concrete: In the determination of split tensile strength of cylindrical concrete specimen, the procedure was in accordance with [13]. The cylinder were cast for cement replacement levels at $0 \%, 5 \%, 7.5 \%, 10 \%, 12.5 \%, 15 \%$ and $20 \%$, and cured for 7 days, 14 days, 21 days and 28 days respectively. For each mix, 3 cylindrical specimens were crushed to obtain the average strength of the concrete samples. Jig with packing strips and loading pieces were carefully positioned along the top and bottom of the plane of loading if the specimen. The jig was then place on the machine so that the specimen is placed centrally. The upper platen was parallel to the lower platen. The load was applied steadily and without shock such that the stress in increased at a rate within the range of $0.04 \mathrm{MPa} / \mathrm{s}$ to $0.06 \mathrm{MPa} / \mathrm{s}$, the rate was maintained at $\pm 10 \%$ until failure. The split tensile strength Fct in $\mathrm{N} / \mathrm{mm}^{2}$ was computed using equation 1 .

$\mathrm{Fct}=\frac{2 F}{\pi \times \mathrm{Lxd}}$ where $\ldots \ldots \ldots-\ldots . \ldots-\ldots(1)$

$\mathrm{F}$ is the maximum load in $(\mathrm{KN})$

$\mathrm{L}$ is the average measured length in $(\mathrm{mm})$

$\mathrm{d}$ is the average measured diameter in $(\mathrm{mm})$

The spilt tensile strength is measured is expressed to the nearest $0.05 \mathrm{MPa}$.

Flexural Strength Test for volcanic ash blended cement concrete: In the determination of flexural strength of concrete beams, the procedures as in accordance with [12] were followed. The beams were cast for cement replacement levels at $0 \%, 5 \%, 7.5 \%, 10 \%, 12.5 \%, 15 \%$ and $20 \%$, of volcanic ash and cured for 7 days and 28 days respectively. 
For each mix, 3 beams were crushed to obtain the average strength of the concrete samples. The compressive strength is the ratio of the weight of cube and the cross sectional area.

Specific Gravity: In determining the specific gravity of aggregate a pycnometer (a vessel of 1 litre capacity with a metal conical screw top and a $5 \mathrm{~mm}$ diameter hole at it apex, giving a water tight connection), tray, scoop, drying cloth and weighing balance were used. The test procedure was carried out in accordance to [14]. The apparatus used during the test include density bottle and stopper, funnel, spatula and weighing balance.

The specific gravity of aggregates was calculated using equation 2.

$\mathrm{Gs}=\frac{C-A}{(B-A)(D-A)}=$

Where: A is the weight of empty density bottle and it is stopper which it was clean and dried

$\mathrm{B}$ is the weight of empty density bottle plus water

$\mathrm{C}$ is the weight of empty density bottle plus aggregate sample

$\mathrm{D}$ is the weight of empty density bottle plus water plus aggregate sample

Bulk Density and Voids: In determining the bulk density and void for volcanic ash a weighing balance, metal cylinder of $7 \mathrm{dm}^{3}$ capacity, scoop, straight edge, tamping rod of $16 \mathrm{~mm}$ diameter and a drying duster (towel) were used. The test was carried out according to the [15]. The bulk density of aggregates was calculated using equation 3 .

$\mathrm{D}=\frac{M}{V}=$

Where $\mathrm{D}$ is the density of the aggregate specimen in $\mathrm{kg} / \mathrm{m} 3$

$\mathrm{M}$ is the mass of the aggregate specimen in $\mathrm{kg}$

$\mathrm{V}$ is the volume of the aggregate specimen in $\mathrm{m} 3$

Also mass of the aggregates sample was determined by subtracting the weight of empty container from the weight of container plus aggregate sample using equation 4 .

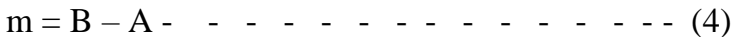

Where $\mathrm{m}$ is the mass of the aggregate specimen in $\mathrm{kg}$

$\mathrm{A}$ is the weight of the empty container in $\mathrm{kg}$

$\mathrm{B}$ is the weight of container plus aggregate sample in $\mathrm{kg}$

III. RESULTS AND DISCUSSION

Chemical Analysis: The result of the chemical analysis showing the oxide composition of VA is presented in Table 1. The total combined content of silica, alumina and ferric oxides was $74.8 \%$. ASTM C618 (1981) specifies that for a pozzolana to be used as a cement blend in concrete it requires a minimum $70 \%$ amount combined of silica, alumina and ferric oxides. Hence VA from Kernag Mangu of Plateau State Nigeria is suitable and can be used as a pozzolana.

Specific Gravity: The specific gravity of aggregate and volcanic ash is presented in Table 2, 3 and 4 . The result shows that specific gravity of coarse aggregate is 2.77 ; also the specific gravity of fine aggregate is 2.64 , while that of volcanic ash is 3.28 .

Bulk Density and voids: The bulk density for aggregate and volcanic ash is presented in Table 5, 6 and 7. The result shows that compacted and un-compacted bulk density of coarse aggregate is 1727 and 1398 respectively while the percentage void is 23.53. While the compacted and uncompacted bulk density of fine aggregate is 1525 and 1340 respectively while the percentage void is 13.81 . In addition the compacted and un-compacted bulk density of volcanic ash is 1703 and 1499 respectively while the percentage void is 13.61 .

Workability: The Slump test result is also presented in Figure 1. The slump values increased with increase ratio of VA content except for 5\% replacement which retains same value as that of $0 \%$ replacement mix. According to ENV 206 (1992), $0 \%, 5 \%$ and $7.5 \%$ replacement was in the $\mathrm{S} 1$ classification $(10 \mathrm{~mm}-40 \mathrm{~mm})$ while the remaining of $10 \% \mathrm{t} 0$ $20 \%$ replacement were in the S2 classification $(50 \mathrm{~mm}-$ $90 \mathrm{~mm})$. The result of the Compacting factor test is shown in Figure 2. The values increased with the increase in the proportion of VA content and with highest value at $20 \%$ cement replacement, however this further confirmed the use of VA as possessing pozzolanic characteristics. The Compacting factor values can be categorized as very low (0.78), low (0.85), medium (0.92) and high (0.95) in accordance with Building research establishment and specified by Neville and Brooks (2010).

Density of the volcanic ash blended cement Concrete: The results of the density test are shown in Figure 1, 2 and 3 From figure 3 , the densities of concrete cubes at $5 \%, 7.5 \%$, $10 \%$ and $12.5 \%$ shows higher densities at 28 days curing period as compared to the control concrete specimen, while the density at $20 \%$ replacement level shows decrease in density of the cubes specimen as compared to the control. In addition, the density of the cylindrical from figure 4 shows that $5 \%$ has higher density than control specimen while other replacement level shows lesser density than the control specimen. From figure 5 presenting the density beam, the result shows that $5 \%, 7.5 \%, 10 \%$ and $12.5 \%$ has higher densities than the control specimen, while $15 \%$ replacement ratio has same density with the control specimen $20 \%$ has lower density as compared to the control specimen.

Compressive strength of the volcanic ash blended cement Concrete: The results of the compressive strength test are shown in Figure 6. At 7 days the result shows increased compressive strength with from $5 \%$ to $10 \%$ replacement of cement with volcanic ash as compared to $0 \%$ control concrete, which shows increase in strength of $0.56 \%$ at $5 \%$ cement replacement, $1.65 \%$ strength increase at $7.5 \%$ and 3.76 increase in strength at $10 \%$ as compared to $0 \%$ replacement, while cement replacement above $10 \%$ shows reduction in strength as compared to $0 \%$ plain concrete. In addition at 14 days and 21 days curing ages the strength index shows that at 5\%,7.5\% and $10 \%$ shows higher and improved strength above $0 \%$ control concrete. Furthermore at 28 days curing the result of the experimental study shows that $7.5 \%$ and $10 \%$ replacement of cement with volcanic ash indicate higher strength than all other replacement and the control concrete specimen, while 5\% replacement of cement with volcanic ash has same value with the control concrete. The 5\%, 7.5\% and 10\% level replacement shows high strength over the control specimen and other replacement levels, however higher replacement levels beyond 10\% shows decrease in strength index. It is indubitable that $10 \%$ replacement level produces the optimum strength. However the trend of the compressive strength shows that replacing cement with $10 \%$ shows it is the ideal replacement level but up-to $15 \%$ shows improved and promising strength. 
Split tensile strength of the volcanic ash blended cement Concrete: The results of the tensile strength test are shown in Figure 7 . The tensile strength at 7 days shows increased strength index at 5\% - $15 \%$ beyond the control concrete, while above $15 \%$ the strength decreases. At 14 days replacement level at 5\%,7.5\% and $10 \%$ shows better strength than $0 \%$ but above $10 \%$ replacement ratios shows reduction in strength as compared to the control specimen. At 21 days the strength of concrete at the strength index shows same properties at $5 \%, 7.5 \%$ and $10 \%$ indicated better strength than $0 \%$ cement replacement, while at 28 days curing ages $7.5 \%$ and $10 \%$ cement replacement levels shows increased strength above plain concrete. While $15 \%$ replacement level shows same strength index with $0 \%$ replacement but better than 5\%, $12.5 \%$ and $20 \%$ replacement levels. However $7.5 \%$ and $10 \%$ shows better strength than $0 \%$ and it was obvious that $10 \%$ present optimum cement replacement.

Flexural strength volcanic ash blended cement Concrete: The results of the flexural strength test are shown in Figure 8. The flexural strength was tested at 7 and 28 days only. At 7 days the strength of the beams at $5 \% 7.5 \%, 10 \%$ and $12.5 \%$ increased beyond the control, while $15 \%$ has same value with the control specimen. Furthermore at 28 days 5\%, 7.5\%, 10\% and $15 \%$ increased beyond the control at $0 \%$, while $12.5 \%$ maintain same strength index with $0 \%$ replacement ratio. $20 \%$ cement replacement shows decreased in strength as compared to the control sample. It is apparent that $10 \%$ replacement level produces the optimum strength. However the optimum volcanic ash replacement ratio of cement is $10 \%$.

Table 1: Energy Dispersive X-Ray Fluorescence (EDXRF) Method of kerang Mangu Volcanic Ash

\begin{tabular}{|c|c|c|}
\hline Elements & & $\%$ Composition \\
\hline Aluminum Oxide $\left(\mathrm{Al}_{2} \mathrm{O}_{3}\right)$ & 18.60 & \\
\hline Silicon Oxide $\left(\mathrm{SiO}_{2}\right)$ & & 32.10 \\
\hline Iron Oxide $\left(\mathrm{Fe}_{2} \mathrm{O}_{3}\right)$ & & 24.10 \\
\hline Potassium Oxide $\left(\mathrm{K}_{2} \mathrm{O}\right)$ & 0.70 & \\
\hline Calcium Oxide $(\mathrm{CaO})$ & & 2.30 \\
\hline Titanium Oxide $\left(\mathrm{TiO}_{2}\right)$ & & 3.50 \\
\hline Vanadium Oxide $\left(\mathrm{V}_{2} \mathrm{O}_{5}\right)$ & N.D & \\
\hline Chromium Oxide $\left(\mathrm{Cr}_{2} \mathrm{O}_{3}\right)$ & 0.03 & \\
\hline Manganese Oxide (MnO) & 0.10 & \\
\hline Magnesium Oxide (MgO) & 2.10 & \\
\hline Nickel Oxide (NiO) & & 0.30 \\
\hline Sodium Oxide $\left(\mathrm{Na}_{2} \mathrm{O}\right)$ & & 0.10 \\
\hline Sulphur trioxide $\left(\mathrm{SO}_{3}\right)$ & N.D & \\
\hline Loss on Ignition (LOI) & 14.20 & \\
\hline
\end{tabular}

Table 2: Specific Gravity Test on Coarse Aggregate

\begin{tabular}{lccc}
\hline Trial & Trial 1 & Trial 2 & Trial 3 \\
\hline Weight of empty cylinder $\left(\mathrm{M}_{1}\right) \mathrm{g}$ & 117.4 & 117.6 & 117.6 \\
Weight of cylinder + sample $\left(\mathrm{M}_{2}\right) \mathrm{g}$ & 224.7 & 257.8 & 255.1 \\
Weight of cylinder + water + sample $\left(\mathrm{M}_{3}\right) \mathrm{g}$ & 504.6 & 524.6 & 525.2 \\
Weight of cylinder + water (M4) g & 496.2 & 436.8 & 435.3 \\
Specific Gravity = $\frac{\mathrm{M} 2-\mathrm{M} 1}{(\mathrm{M} 4-\mathrm{M} 1)-(M 3-M 2)}$ & 2.75 & 2.68 & 2.89 \\
Average Specific Gravity & & 2.77 & \\
\hline
\end{tabular}

Table 3: Specific Gravity Test on Fine Aggregate

\begin{tabular}{|c|c|c|c|}
\hline Trial & Trial 1 & Trial 2 & Trial 3 \\
\hline Weight of empty cylinder $\left(\mathrm{M}_{1}\right) \mathrm{g}$ & 13.7 & 12.4 & 13.6 \\
\hline Weight of cylinder + sample $\left(\mathrm{M}_{2}\right) \mathrm{g}$ & 646.3 & 308.2 & 628.2 \\
\hline Weight of cylinder + water + sample $\left(\mathrm{M}_{3}\right) g$ & 646.3 & 308.2 & 628.2 \\
\hline Weight of cylinder + water (M4) g & 596.0 & 247.2 & 594.5 \\
\hline Specific Gravity $=\frac{\mathrm{M} 2-\mathrm{M} 1}{(\mathrm{M} 4-\mathrm{M} 1)-(M 3-M 2)}$ & 2.49 & 2.92 & 2.52 \\
\hline Average Specific Gravity & & 2.64 & \\
\hline
\end{tabular}

Table 4: Specific gravity test on Volcanic Ash

\begin{tabular}{lllll}
\hline Trial & & Trial 1 & Trial 2 & \multicolumn{1}{c}{ Trial 3 } \\
\hline Weight of empty cylinder $\left(\mathrm{M}_{1}\right) \mathrm{g}$ & 13.4 & & 13.6 & 13.7 \\
Weight of cylinder + sample $\left(\mathrm{M}_{2}\right) \mathrm{g}$ & 64.5 & & 65.2 & 65.2 \\
Weight of cylinder + water + sample $\left(\mathrm{M}_{3}\right) \mathrm{g} 119.6$ & 84.1 & 119.3 & 119.6 \\
Weight of cylinder + water (M4) g & 83.8 & 83.4 \\
\hline
\end{tabular}


Specific Gravity $=\frac{\mathrm{M} 2-\mathrm{M} 1}{(\mathrm{M} 4-\mathrm{M} 1)-(M 3-M 2)}$

Table 5: Bulk Density for Coarse Aggregate

Trials

Weight of empty cylinder $\left(\mathrm{M}_{1}\right) \mathrm{kg}$

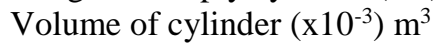

Weight of cylinder + sample $\left(\mathrm{M}_{2}\right)$

Weight of sample $\left(\mathrm{M}_{2}-\mathrm{M}_{1}\right) \mathrm{kg}$

Bulk density $\rho=\frac{\mathrm{M} 1-\mathrm{M} 2}{\text { volume }}$

Average $=\frac{\mathrm{C} 1+\mathrm{C} 2+\mathrm{C} 3}{3}$

Percentage void $\rho=$ weight of compacted CA - weight of uncompacted CA weight of uncompacted of CA
COMPACTED

\section{UNCOMPACTED}

$\begin{array}{llllllll} & \text { C1 } & \text { C2 } & \text { C3 } & & \text { C1 } & \text { C2 } & \text { C3 } \\ 8.10 & 8.10 & 8.10 & & 8.10 & 8.10 & 8.10 & \\ 1.55 & 1.55 & 1.55 & & 1.55 & 1.55 & 1.55 & \\ 11.01 & 10.68 & 10.64 & & 10.25 & 10.29 & 10.26 & \\ 2.91 & 2.58 & 2.54 & & 2.15 & 2.19 & 2.16 \\ 1877 & 1665 & 1639 & & 1387 & 1413 & 1394 & \\ & 1727 & & & & 1398 & & \end{array}$

23.53

Table 6: Bulk Density for Fine Aggregate

\begin{tabular}{|c|c|c|c|c|c|c|c|c|}
\hline \multirow{2}{*}{ Trials } & & \multicolumn{3}{|c|}{ COMPACTED } & \multicolumn{4}{|c|}{ UNCOMPACTED } \\
\hline & & C1 & $\mathrm{C} 2$ & C3 & & C1 & $\mathbf{C 2}$ & $\mathbf{C 3}$ \\
\hline Weight of empty cylinder $\left(\mathrm{M}_{1}\right) \mathrm{kg}$ & 8.10 & 8.10 & 8.10 & & 8.10 & 8.10 & 8.10 & \\
\hline Volume of cylinder $\left(\times 10^{-3}\right) \mathrm{m}^{3}$ & 1.55 & 1.55 & 1.55 & & 1.55 & 1.55 & 1.55 & \\
\hline Weight of cylinder + sample $\left(\mathrm{M}_{2}\right)$ & 10.46 & 10.45 & 10.48 & & 10.14 & 10.20 & 10.19 & \\
\hline Weight of sample $\left(\mathrm{M}_{2}-\mathrm{M}_{1}\right) \mathrm{kg}$ & 2.36 & 2.35 & 2.38 & & 2.04 & 2.10 & 2.09 & \\
\hline Bulk density $\rho=\frac{\mathrm{M} 1-\mathrm{M} 2}{\text { volume }}$ & 1523 & 1516 & 1535 & & 1316 & 1355 & 1348 & \\
\hline Average $=\frac{\mathrm{C} 1+\mathrm{C} 2+\mathrm{C} 3}{3}$ & & 1525 & & & & 1340 & & \\
\hline Percentage void $\rho=\frac{\text { weight of compa }}{\text { weig }}$ & $\frac{\text { veight of }}{\text { mpacted }}$ & $\frac{\text { icompac }}{\text { FA }}$ & $\mathrm{dFA}$ & & 13.81 & & & \\
\hline
\end{tabular}

Table 7: Bulk Density for Volcanic Ash

\begin{tabular}{|c|c|c|c|c|c|c|c|c|}
\hline \multirow[b]{2}{*}{ Trials } & & \multicolumn{3}{|c|}{ COMPACTED } & \multicolumn{4}{|c|}{ UNCOMPACTED } \\
\hline & & C1 & $\mathrm{C2}$ & C3 & & C1 & $\mathbf{C 2}$ & C3 \\
\hline Weight of empty cylinder $\left(\mathrm{M}_{1}\right) \mathrm{kg}$ & 8.10 & 8.10 & 8.10 & & 8.10 & 8.10 & 8.10 & \\
\hline Volume of cylinder $\left(\times 10^{-3}\right) \mathrm{m}^{3}$ & 1.55 & 1.55 & 1.55 & & 1.55 & 1.55 & 1.55 & \\
\hline Weight of cylinder + sample $\left(\mathrm{M}_{2}\right)$ & 10.72 & 10.75 & 10.75 & & 10.41 & 10.43 & 10.43 & \\
\hline Weight of sample $\left(\mathrm{M}_{2}-\mathrm{M}_{1}\right) \mathrm{kg}$ & 2.62 & 2.65 & 2.65 & & 2.31 & 2.33 & 2.33 & \\
\hline Bulk density $\rho=\frac{\text { M1-M2 }}{\text { volume }}$ & 1690 & 1710 & 1710 & & 1490 & 1503 & 1503 & \\
\hline Average $=\frac{\mathrm{C} 1+\mathrm{C} 2+\mathrm{C} 3}{3}$ & & 1703 & & & & 1499 & & \\
\hline
\end{tabular}

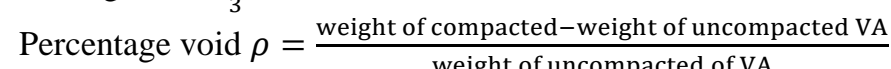
weight of uncompacted of VA

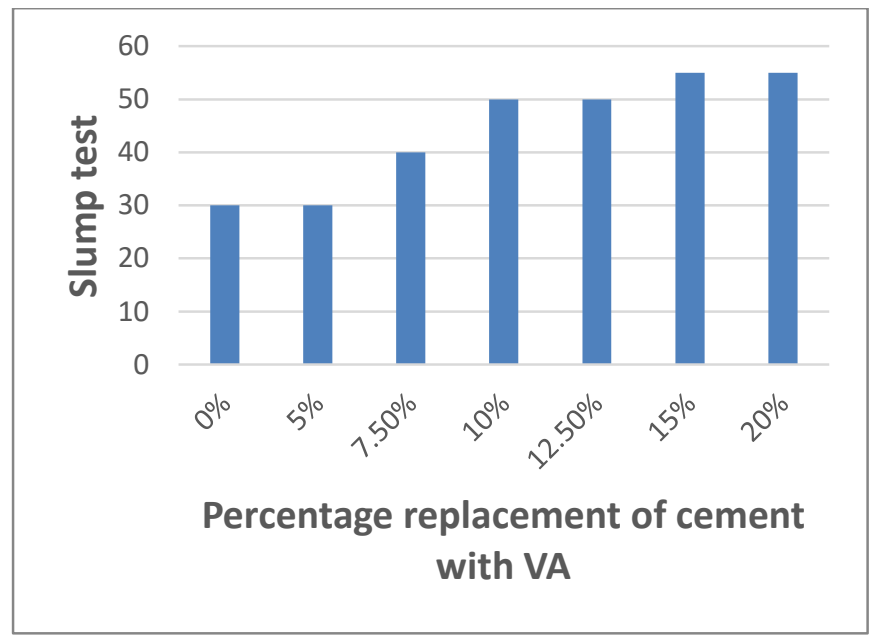

Figure 1: Slump Test

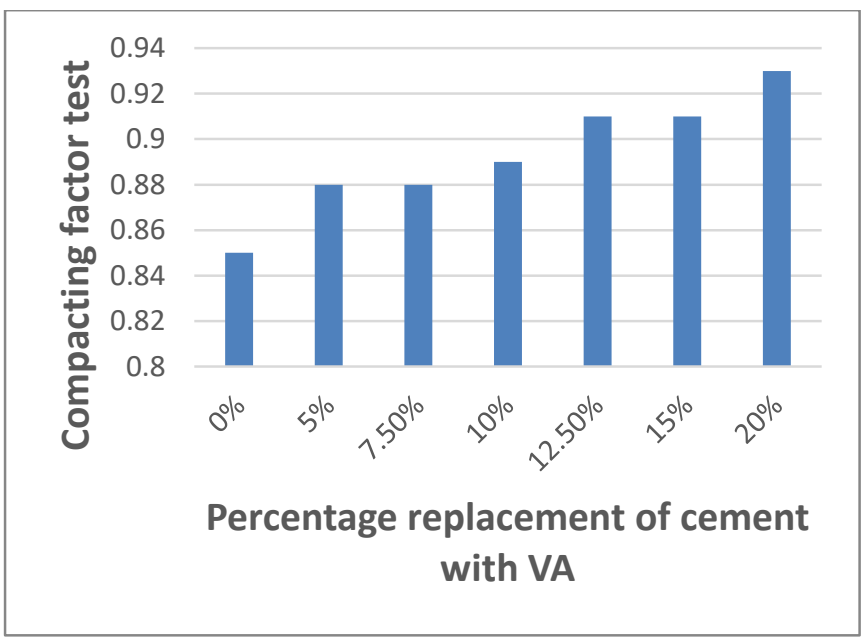

Figure 2: Compacting Factor Test 

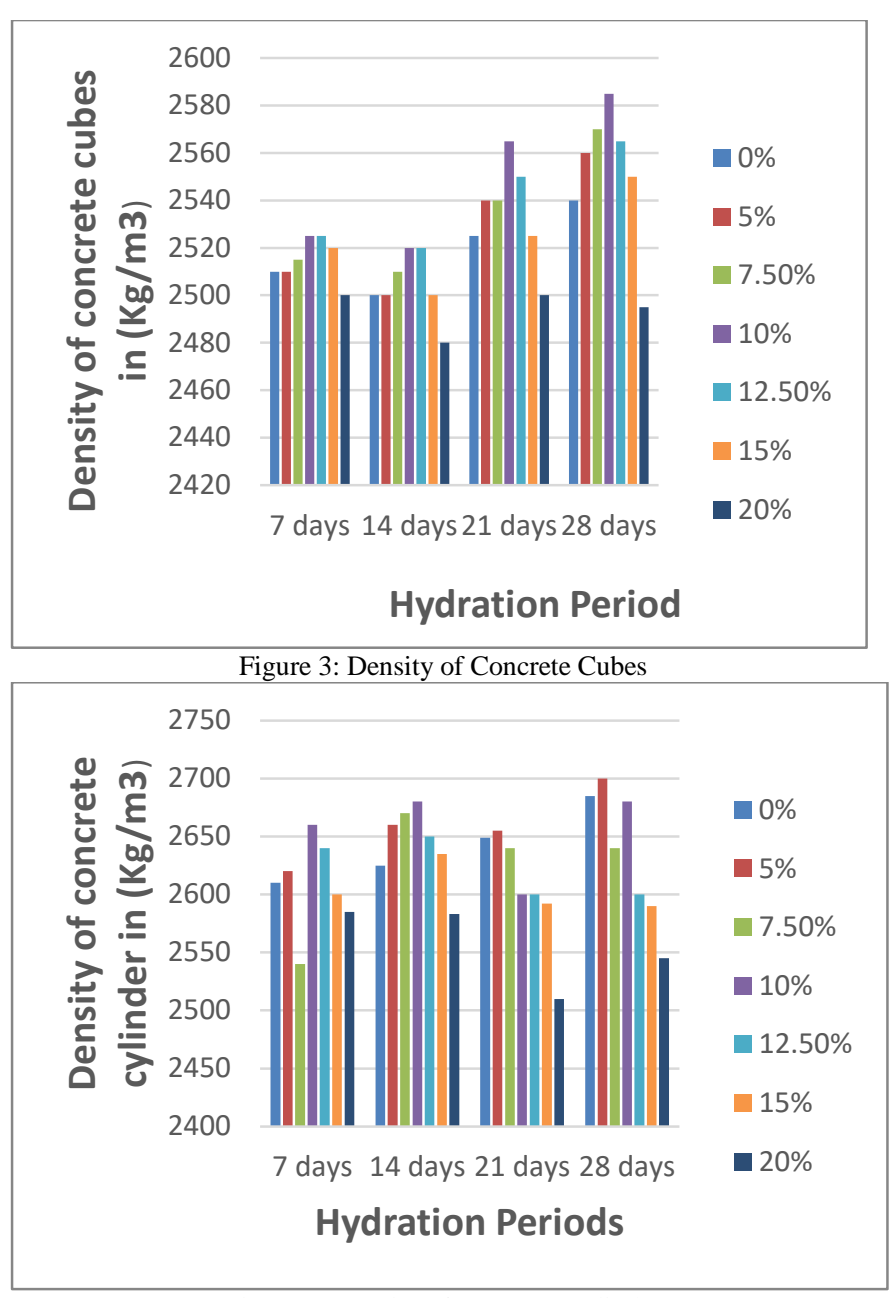

Figure 4: Density of Concrete Cylinder

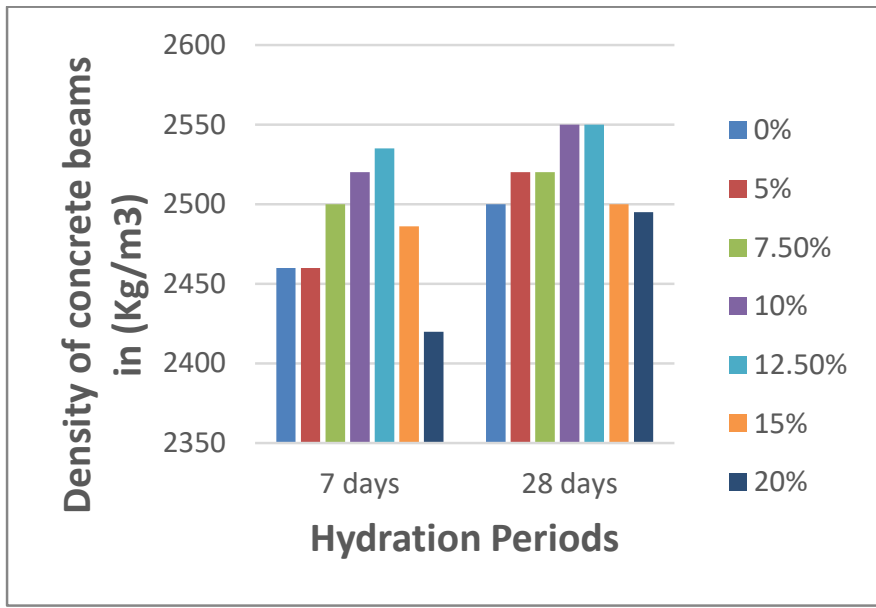

Figure 5: Density of Concrete Beams

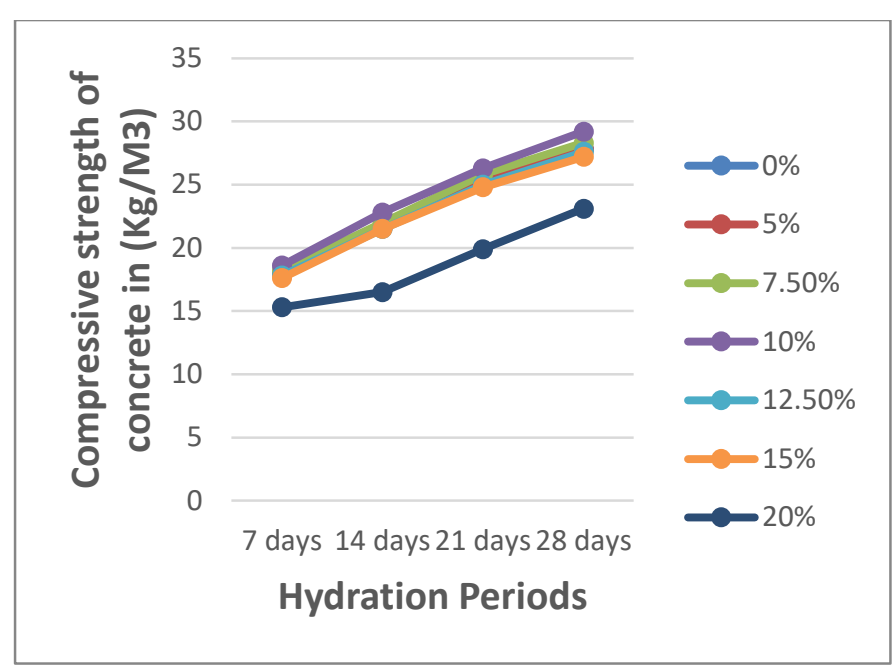

Figure 6: Compressive Strength of Concrete

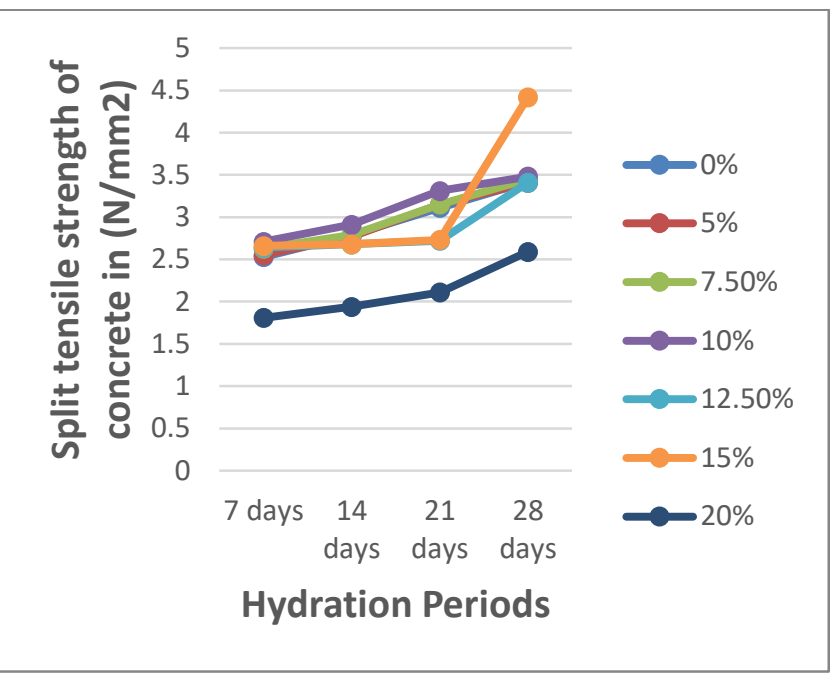

Figure 7: Split Tensile Strength of Concrete

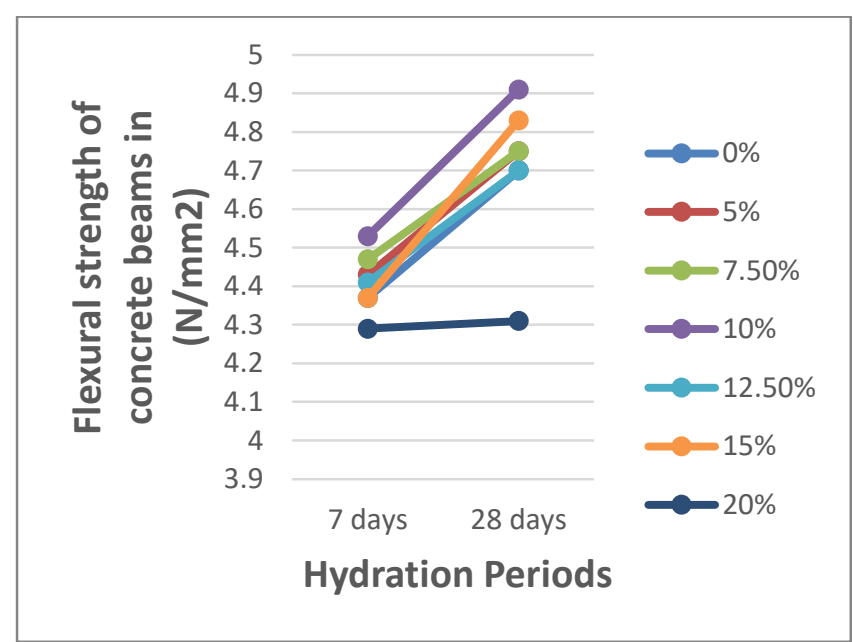

Figure 8: Flexural Strength of concrete

IV. CONCLUSION

Volcanic ash was cleaned, dried, then grinded and sieved. The oxide composition of the ash showed that it possess and can be used as a pozzolanic material with essential constituent of a pozzolana which include $32.1 . \% \mathrm{SiO}_{2} \quad 18.6 \%$ $\mathrm{Al}_{2} \mathrm{O}_{3}$ and $24.1 \% \mathrm{Fe}_{2} \mathrm{O}_{3}$ content summing up-to to $74.8 \%$ as 
presented in table 1 . The VA was used to replace cement at $5 \%-20 \%$ in ratios. The workability of the fresh mixes fell within the low and medium classifications. The Compressive strengths declined at above $10 \%$ replacement level of cement at 28 days curing, the result also which indicates up-to $15 \%$ replacement levels meet the requirement of BS EN 206-1: 2000 for class C25/30 and C20/25 respectively for heavy weight concreting and LC25/28 and LC20/22 respectively for light weight concreting. In addition at 28 days the tensile strength decreased above $15 \%$ while the flexural strength also decreases at above $15 \%$ replacement levels; however $10 \%$ replacement level presents the highest strength index. The study suggests that volcanic ash could be replaced up-to $15 \%$ with $10 \%$ replacement level having the best mix using W/C ratio of 0.5 . The density related values shows similar result with reduced density above $15 \%$ cement replacement with volcanic ash at 28 days. The research concluded that volcanic ash is a good pozzolanic material for concrete and at $10 \%$ optimum replacement levels can produce very strong concrete but can be used up-to $15 \%$. Further study are recommended on other properties such as setting times, water absorption capacity, permeability, shrinkage resistance, fire resistance, durability on concrete and mortars made with volcanic ash cement replacements, Admixtures may be added to improve performance, also using a different mix and altering water cement ratio is also recommended.

\section{REFERENCES}

[1] Shoubi, M. V., Barough, A. S. and Amirsolemani, O. (2013). Assessment of the Roles of Various Cement Replacements in Achieving the Sustainable and High Performance Concrete. International Journal of Advances in Engineering and Technology, 6(1), 68-77.

[2] Dahiru, D. (2010). Problem of Ready-Mix Concrete Production in the Construction Industry in Nigeria and its Cost Implication. Paper presented on West Africa Built Environment Research (WABER) Conference 27-28 July, 2010, Accra, Ghana, 445-457.

[3] American Society for Testing and Material. (2005). Specification for Fly Ash and Raw or Calcined Natural Pozzolana or Use in as a
Mineral Admixture in Portland cements Concrete. American Society for Testing and Material, West Conshohocken, No C618. USA.

[4] Shetty, M. S. (2009). Concrete Technology; Theory and Practice, S Chad and Company, New Delhi, India, 174-418

[5] Olawuyi, B. J., Olusola, K. O. and Babafemi, A. J. (2012). Influence of Curing Age and Mix Composition on Compressive Strength of Volcanic Ash Blended Cement Laterized Concrete. Civil Engineering Dimension, 14(2), 84-91.

[6] Osei, D. Y. and Jackson, E. N. (2012). Compressive Strength and Workability of Concrete Using Natural Pozzolan as Partial Replacement of Ordinary Portland Cement. Journal of Advances in Applied Science Research, 3(6), 3658-3662. Retrieved from http://www.pelagiaresearchlibrary.com

[7] Joergensen, S. W. (2014). Grinding of Clinker Replacement Materials. Special Report by General Manager Grinding Technology, 1-15.

[8] Mukherjee, S., Mandal, S. and Adhikari, U. B. (2012). Study on the Physical and Mechanical Property of Ordinary Portland Cement and Fly Ash Paste. International Journal of Civil and Structural Engineering, 2(3), 731-736. Doi:10.6088/ijcser.00202030003.

[9] Mahmoud, H., Belel, Z. A. and Nwakaire, C. (2012). Groundnut Shell Ash as a Partial Replacement of Cement in a Sandcrete Blocks Production. International Journal of Development and Sustainability, 1(3), 1026-1032. Retrieved from http://www.isdsnet.com/ijds

[10] Dadu, D. W. (2011). Investigation into Pozzolanic Characteristics of Jos Plateau Volcanic Deposits for Partial Replacement of Portland Cement in Concrete. Unpublished Ph. D Dissertation Work. Department of Building Faculty of Environmental Design, Ahmadu Bello University Zaria, Nigeria.

[11] British Standard, (1983). Testing concrete; Method for determination of slump. BS 1881-102, BSI, Linfordwood, Milton Keynes MK14 6LE, U.K.

[12] British Standard Institution (1983) Method for Determination of Compressive Strength of Concrete Cube, BS 1881: Part 116, London, British Standard Institution.

[13] BS1881 - 117: 1983. Testing Concrete - Method for determination of tensile splitting strength. British Standards Institute, London

[14] British Standard 1377 part 2 (1970). Methods of determination Specific gravity of aggregate. BSI Publication British Standard Institution, London.

[15] British Standard 812 part 2 (1995).Testing aggregate part 2.Methods of determination of bulk density. BSI Publication British Standard Institution, London. 